\title{
Development of Mobile Learning for General Courses Indonesian Language Education as An Effort to Improve the Quality of Lectures at Education Universities in Indonesian
}

\author{
Ucu Cahyana ${ }^{1}$, Maria Paristiowati ${ }^{1{ }^{1 *},}$ N. Lia Marliana ${ }^{2}$, Siti Ansoriyah ${ }^{2}$, Rifkah Nabilah ${ }^{1}$, \\ Rahma Dwi Pasha ${ }^{1}$, Theodorus Panglila ${ }^{3}$, Revolson A. Mege ${ }^{4}$ \\ ${ }^{1}$ Department of Chemistry Education, Faculty of Mathematics and Science, Universitas Negeri Jakarta, Jakarta, Indonesia \\ ${ }^{2}$ Department of Indonesia Languages, Faculty of Languages and Art, Universitas Negeri Jakarta, Jakarta, Indonesia \\ ${ }^{3}$ Department of Civic Education, Faculty of Social Science, Universitas Negeri Manado, Manado, Indonesia \\ ${ }^{4}$ Department of Biology Education, Faculty of Mathematics and Science, Universitas Negeri Manado, Manado, Indonesia
}

Received June 24, 2020; Revised August 1, 2020; Accepted August 25, 2020

\section{Cite This Paper in the following Citation Styles}

(a): [1] Ucu Cahyanal, Maria Paristiowati, N. Lia Marliana, Siti Ansoriyah, Rifkah Nabilah, Rahma Dwi Pasha, Theodorus Panglila, Revolson A. Mege, "Development of Mobile Learning for General Courses Indonesian Language Education as An Effort to Improve the Quality of Lectures at Education Universities in Indonesian, "Universal Journal of Educational Research, Vol. 8, No. 10, pp. 4684-4691, 2020. DOI: 10.13189/ujer.2020.081037.

(b): Ucu Cahyana1, Maria Paristiowati, N. Lia Marliana, Siti Ansoriyah, Rifkah Nabilah, Rahma Dwi Pasha, Theodorus Panglila, Revolson A. Mege (2020). Development of Mobile Learning for General Courses Indonesian Language Education as An Effort to Improve the Quality of Lectures at Education Universities in Indonesian. Universal Journal of Educational Research, 8(10), 4684-4691. DOI: 10.13189/ujer.2020.081037.

Copyright $\mathrm{C} 2020$ by authors, all rights reserved. Authors agree that this article remains permanently open access under the terms of the Creative Commons Attribution License 4.0 International License

\begin{abstract}
Problems with conducting general course lectures are partly due to the insufficient availability of qualified teaching staff so it becomes necessary to employ lecturers that are not employed by the University from outside or join some classes into one class. Problems from the lecturer side are more to the variety of methods used. Joining class has all sorts of negative implications including providing the specific learning resources needed by each cohort and of course places tremendous pressure on the lecturer managing joined class. This research aims to develop learning media in the form of mobile learning in Indonesian language courses. The study was conducted at several universities in Indonesia. The research method used in this study was the research and development mobile learning for general courses Indonesian language followed by the implementation of the product using quantitative and qualitative research methods. The resulting mobile learning media is an application for smartphones with an android operating system called "Indonesian.apk".
\end{abstract}

Learning components included in the application are: learning videos, materials and quizzes. At the stage of the media feasibility test by material and language experts, the percentage of overall average assessment was $77.08 \%$. In the feasibility test stage by media, experts produced an average assessment percentage of $90.53 \%$. The results of small-scale trials of students amounted to $90.2 \%$ and the results of large-scale trials of students amounted to $93.4 \%$. Overall, the results of the media trial resulted in an assessment of the media with very good average criteria. Based on the calculation of the results of the t-test test, it shows that by using mobile learning there is a significant difference between the pre-test and post-test scores of students. The average post-test scores in the experimental class are higher than the lecturer delivered teaching and learning.

Keywords Mobile Learning, General Courses, Indonesian Language Course 


\section{Introduction}

The Indonesian Higher Education curriculum includes several subjects, there are: religion, Pancasila, citizenship, and Indonesian. These four courses are grouped as general courses with the distribution of credits as follows: religion 3 credits, Pancasila 2 credits, citizenship 2 credits and Indonesian language 2 credits. This general course it is compulsory to study all four components and achieve at least a pass standard in each component by all students in all tertiary institutions in Indonesia, including education universities in Indonesia.

Some problems in organizing general courses lectures in Indonesia include the availability of suitable specialist academic staff it becomes necessary to employ lecturers that are not employed by the University from outside or join some classes into one class with more than eighty students per class. Problems from the lecturer side are more to the variety of methods used. These conditions resulted in less optimal learning processes and student learning outcomes in general courses. Abdullah said that in the context of education in Indonesia, Islamic education in higher education is not new [1]. This situation encourages academics to consider alternatives in education innovation and transformation, both in terms of material and methodology of study.

There are several components that need to be developed in Indonesian language learning courses that are part of general courses, namely learning methods, sources and learning materials that are still limited to the use of books, as well as assessments that are oriented towards results assessment. These conditions resulted in less optimal learning processes and student learning outcomes in general courses. One of the learning resources that can be used by lecturers is learning media. Learning media are used to channel messages that can stimulate the mind, attention and willingness of students to learn [5].

Interesting learning design that used mobile learning is very important to do in the current situation. The development of mobile learning that can be accessed by students with rich material that will enrich general courses learning is interesting. Learning media using mobile phones is one type of mobile learning media [12]. Mobile learning allows students to learn and develop digital skills in addition to being able to overcome the shortage of general courses lecturers. Mobile learning makes the learning process fun and is in accordance with the character of the times and makes technology synergize with the spirit of education as a learning process that is not only in the lecture hall [9]. Apart from that, mobile learning media can minimize learning difficulties in study because the material in mobile learning is concise, easy to understand, and flexible (does not have to carry books) which makes students' enthusiasm to learn high so students can do learning well [4]. Learning by using mobile learning makes it easy for students to learn at any time and utilize their free time with learning activities [17]. Mobile learning can be used by students as the latest technology in the independent learning process. Mobile technology includes media information in the form of text, audio, video, images, graphics and communication media for interaction between various members [2]. So the mobile learning application can contain subject matter, learning videos, and question quizzes that are developed in accordance with the curriculum.

This research is a higher education research consortium scheme that refers to the national research master plan in the areas of social focus, humanities, arts and culture, and education, namely on the topic of educational technology development. This research is also in accordance with research topics at the research consortium in social, humanities, arts and culture, and education, namely: "Development of Diversity-Based Digital Media, Local Wisdom to Build Nation Integration". This research can contribute policy concepts to the ministry of research, technology and higher education in an effort to improve the quality of general courses learning, through the development of appropriate mobile learning media.

\section{Method}

This study aims to produce mobile learning for general courses consisting of Indonesian language courses. The resulting product was tested for eligibility by experts from several education universities in Indonesia, and limited trials in several education universities in Indonesia. The research was conducted in several stages. Research and development (R\&D) refers to research developed by Borg and Gall with using a structured process with the following phases:

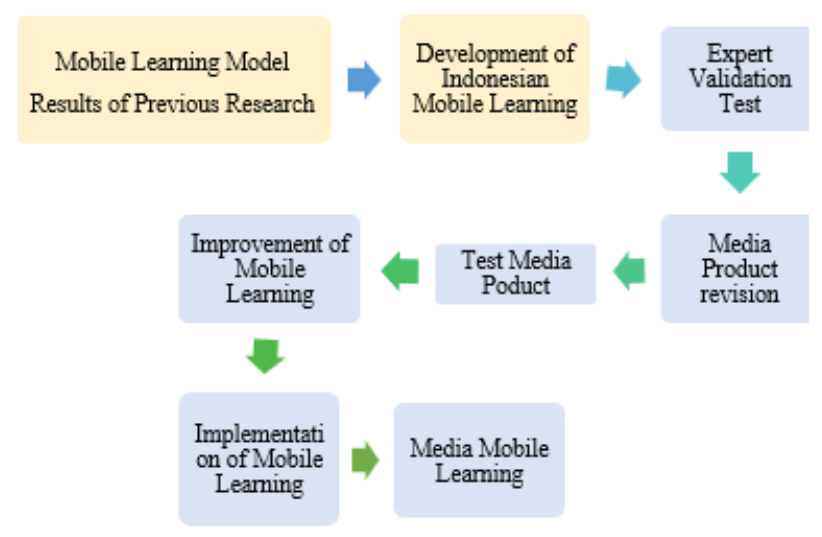

Figure 1. Development of general courses mobile learning media and limited trials

Data collection techniques in this study use a questionnaire to validation media mobile learning by expert and students. 
Questionnaire data are then processed and analyzed to be used as a reference in developing mobile learning products. The rating scale used in the questionnaire is the Likert scale.

Table 1. Likert Scale assessment

\begin{tabular}{|c|c|}
\hline Answer & Score Weights \\
\hline Strongly agree & 4 \\
\hline Agree & 3 \\
\hline Disagree & 2 \\
\hline Strongly disagree & 1 \\
\hline
\end{tabular}

To calculate the percentage of Likert scale, the percentage of product eligibility formula is used. Percentage results are categorized according to criteria using a rating scale. Product criteria based on the results of research developed are feasible to use if the interpretation is $\geq 60 \%$.

Table 2. Quality Criteria with Rating Scale

\begin{tabular}{|c|c|}
\hline Assessment Level & Information \\
\hline Figures $0-20 \%$ & Very less \\
\hline Figures $21-40 \%$ & Less \\
\hline Figures $41-60 \%$ & Good enough \\
\hline Figures $61-8-\%$ & Good \\
\hline Figures $81-100 \%$ & Very good \\
\hline
\end{tabular}

The reliability tests intra-class coefficients to assess the reliability between two or more observers by using a ratio between variances between groups. The statistical test to calculate reliability in this study uses the Hoyt test [6]. The data obtained are categorized in the reliability criteria as follows:

Table 3. Reliability Category

\begin{tabular}{|c|c|}
\hline Reliability Value & Information \\
\hline $0.0-0.20$ & Poor \\
\hline $0.21-0.40$ & Less than moderate \\
\hline $0.41-0.60$ & Medium \\
\hline $0.61-0.80$ & Good \\
\hline $0.81-1.00$ & Very good \\
\hline
\end{tabular}

In addition, other research instruments used are pre-test and post-test to find out the improvement of student learning outcomes and effectiveness media. The effectiveness test uses quantitative research methods by t-test. During the course of the research, the covid-19 pandemic was taking place, so the research data collection technique was carried out online. Data collection techniques used are quantitative descriptive statistical data in accordance with predetermined indicators by giving a predetermined score weighting.

\section{Results and Discussion}

\subsection{Results of Requirement Analysis by Students}

The need of analysis phase for students is carried out by distributing questionnaires to 32 students of Jakarta State University. The selection of samples as respondents is based on students who have taken general courses in Indonesian. Based on the results of the needs analysis data, $72 \%$ of students stated that in studying Indonesian language courses students had constraints namely the material presented was less interesting and $81 \%$ of students stated there were not many media that helped to study. The most widely used learning resources by students so far are internet, e-book, e-journal etc. This is one of the factors in the lack of information obtained by the participants because the learning resources and learning media used are not accurate. To overcome the obstacles in learning Indonesian language material, $66 \%$ of students agree using learning videos, $72 \%$ of students agree to use smartphones as learning resources and $50 \%$ of agree to increase reading books.

In addition, observations show that all students own and use gadgets in their daily activities. The presence of gadgets among students can be positive if used properly in the learning process, one of them by using it as a tool to support learning resources. Based on this condition, the researcher connects the gadget that students have with the learning resources needed to help students understand Indonesian language material. So that in this study developed a learning application that contains interactive learning resources called mobile learning media. The contents of mobile learning are tailored to the needs of students in learning Indonesian language material, $84 \%$ of which is presented in a concise and complete and $75 \%$ of the video supporting the material. In addition, mobile learning will be developed through quizzes or practice questions, so that learning is more interesting and interactive. Based on the data analysis results $100 \%$ of students agree with the development of mobile learning as a medium to support the learning process.

\subsection{Product Development Stage}

The product development stage is the stage of making media according to the results of the analysis of student needs. In product development, there are two stages there is planning and development.

\subsubsection{Planning Stage}

The planning stage, the determination of learning achievements and media content scenarios. The concept prepared at this stage is the media content scenario which is a picture of the content in mobile learning media, such as materials that are adapted to the latest curriculum, learning videos designed to support material content, assignments as evaluations of student learning, quizzes in the form of 
drag and drop games which can be used by users to play and learn to match several word choices, and practice questions with various difficulty level. At this stage, a story board is created from mobile learning media which is an initial description of the product design that will be developed. By using the story board you will see the flow and direction of mobile learning media systematically. On the story board, you can already see the content's menu and the layout of the content that will be included in the media.

At the planning stage, the selection of software that will be used to develop mobile learning media is also determined. In the development of mobile learning media researchers chose Adobe Flash CS 6 software as the main software processing program and 2-dimensional animation processor, CorelDraw X8 to design content designs from mobile learning media, Microsoft Power Point to design learning videos, Microsoft Word to design content and filmora to edit learning videos and practical videos. The following is a picture of the main software workspace used in developing mobile learning media. (Figure 2)

\subsubsection{Development Stage}

The media development stage is based on the storyboard that has been designed and the selection of software at the planning stage. The product is generously produced from Adobe Flash CS 6 software with results in the form of apk and swf files. The file names generated from Adobe Flash software are "Indonesian.apk" and "Indonesian.swf". File in the form of an APK can be run through a compatible Android smartphone up to the latest version of the Android system, which is v.9.0 Pie with a file size of $185 \mathrm{MB}$ while the swf file can be used via a laptop. Smartphone can be used only in the form of an android operating system. The resulting application is in the form of landscape with a screen size resolution of $2400 \times 1080$ pixels to match the screen size of the current smartphone.

\subsection{The Media Trial Stage}

The trial phase is carried out to determine the quality and feasibility of the media when used in the field. At this stage, several trials were carried out including the feasibility test by experts, small-scale trials by students and lecturers and large-scale media trials by students and lecturers.

Validation test by experts includes material and language experts and media experts. The feasibility test by the expert is carried out in order to obtain constructive comments and suggestions for the further development of media from experts in the field of media and material before being tested by the media to the user, namely by students. The following is a discussion of the results of media trials that have been carried out.

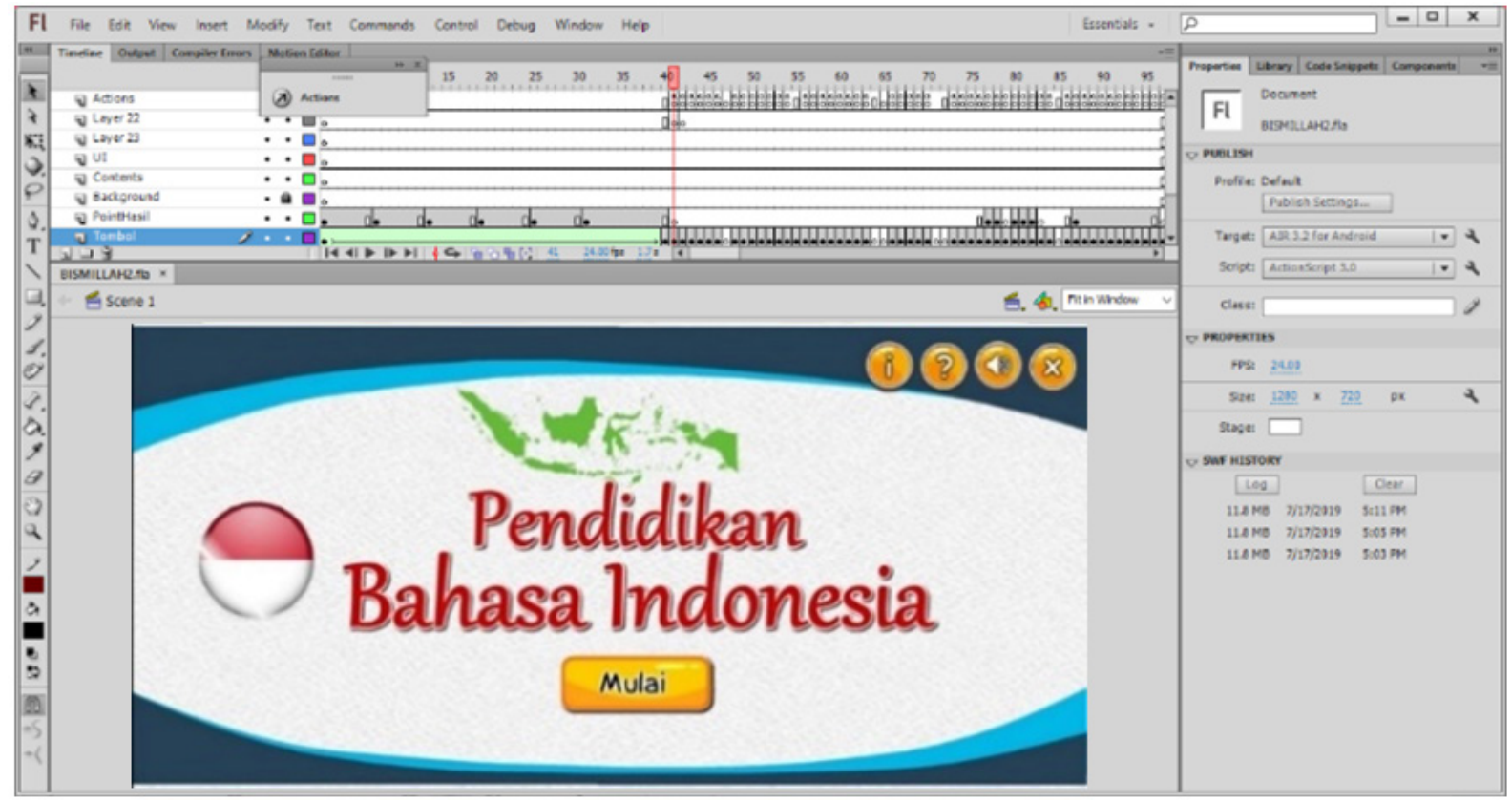

Figure 2. The main workspace software for Adobe Flash CS 6 


\subsubsection{Validation Test by Media Expert}

Validation tests by media experts are carried out to determine the feasibility assessment of mobile learning developed in terms of media components. The feasibility test by the media expert was carried out by one computer science lecturer and two lecturers of FIP UNJ Education Technology. The assessment of the media feasibility test includes two aspects namely, aspects of audio and visual appearance as well as aspects of implementation and software engineering. The instrument used in the assessment of the feasibility of the media was a questionnaire with 15 question items. Based on calculations, a feasibility test was produced by media experts in each aspect as follows:

Table 1. Table of Feasibility Test Results by Media Experts

\begin{tabular}{|c|c|c|c|}
\hline No & Aspect & $\begin{array}{c}\text { Average } \\
\text { Percentage }\end{array}$ & Criteria \\
\hline 1 & Audio and visual display & $89.39 \%$ & Very good \\
\hline 2 & $\begin{array}{c}\text { Implementation and } \\
\text { software engineering }\end{array}$ & $91.67 \%$ & Very good \\
\hline \multicolumn{2}{|c|}{ Average Overall Value } & $90.53 \%$ & Very good \\
\hline
\end{tabular}

Based on the results of the average percentage of the two aspects above, we obtain the average overall assessment of the media by $90.53 \%$. Then it can be concluded that overall aspects of the media that have been used in mobile learning media meet the "very good" assessment criteria. On the results of the feasibility test by media experts, a reliability test was conducted between the rater using the Hoyt test. The reliability test results in the feasibility test are obtained by media experts who were equal to 0.96 . This shows that the consistency of the results of the inter-rater assessment is very good. Audio and visual display in mobile learning media reached very good criteria. While audio and visual word in mobile learning were widely used in video learning. The process of learning through video makes it easy for students to learn, according to [8] learning through video can pause, accelerate and slow down and repeat some important parts essential elements of the video, so students can share at the appropriate speed and can repeat the material they want to know more deeply.

\subsubsection{Validation Test by Material and Language Experts}

Validation tests by material and language experts were carried out to determine the appropriateness assessment of material and language in mobile learning media from material experts, so that the material included in the media is in accordance with the basic competencies, indicators and learning objectives to be achieved by students, and the language used can be easily understood and not cause a double interpretation. The feasibility test of material and language experts was conducted by three Indonesian lecturers. The assessment of the feasibility of the material and language includes three aspects, namely the suitability of the content substance with the competencies that must be achieved, the material presentation aspect and the language aspect. The assessment of the material and language feasibility test was given in the form of a questionnaire with 14 question items. The results of final assessment by material and language experts can be seen in Table 2.

Table 2. Table of Feasibility Test Results by Material Experts

\begin{tabular}{|c|c|c|c|}
\hline No & Aspect & $\begin{array}{c}\text { Average } \\
\text { Percentage }\end{array}$ & Criteria \\
\hline 1 & $\begin{array}{l}\text { The suitability of the substance of } \\
\text { the contents with the competencies } \\
\text { that must be achieved }\end{array}$ & $77,08 \%$ & good \\
\hline 2 & Presentation of Material & $79,17 \%$ & good \\
\hline 3 & Language & $75,00 \%$ & good \\
\hline \multicolumn{2}{|c|}{ Average Overall Value } & $77,08 \%$ & good \\
\hline
\end{tabular}

Based on the results of the average percentage of the five aspects above, the overall assessment of material and language is obtained by $75 \%$. This shows that overall the material and language used in the mobile learning media meet the "good" assessment criteria and are suitable for use in the mobile learning media. On the results of the media feasibility test by material and language experts, a reliability test was conducted between rater using the Hoyt test. The reliability test results by material and language experts are equal to 0.9 . This shows that the consistency of the results of the evaluation among the rater has good criteria.

\subsubsection{Small Scale Media Trial by Students}

The purpose phase of small-scale media aims to obtain information in the form of suggestions and comments from students as users of media that have been developed before the media were used on a large scale. A small-scale media trial was conducted on 15 economic students who were taking Indonesian Language courses. This media trial was conducted by distributing mobile learning applications that have been developed to the smartphones of every student through the website. Before students open the application, students are required to do a pre-test to find out the student's knowledge before entering the material. The questionnaire given consisted of 11 questions.

Based on small-scale media trials, the following comments and suggestions from students were obtained:

"The material is concise and clearly not complicated so it makes it easy for us students to understand it. Suggestions for this application are to be more on the level of animation and appearance to make it even more interesting. Thank you"

(Comments and suggestions, Student 2)

"The learning media for general Indonesian (general courses) courses is already good, and suggestions for time quizzes should be considered so as not to disadvantage students"

(Comments and suggestions, Student 10) 
Suggestions are given by students on a small scale to add time to the quiz so that the time used is exactly in accordance with the reading time of student questions. The mobile learning media developed made it easy for students to understand the material, this is in line with research conducted by [10] mobile learning is easy to understand because learning by mobile learning also makes students able to learn at their own catching speed.

Evaluation of small-scale media using a questionnaire by students consists of five aspects, they're aspects of material, videos and questions, aspects of language, aspects of audio and visual appearance, aspects of management and aspects of software engineering and aspects of usefulness. Based on calculations, the results of small-scale media trials by students in each aspect are as follows:

Table 3. Media Trial Results by Small Scale Students

\begin{tabular}{|c|c|c|c|}
\hline No & Aspect & $\begin{array}{c}\text { Average } \\
\text { Percentage }\end{array}$ & Criteria \\
\hline 1 & $\begin{array}{l}\text { Quality of material, } \\
\text { videos and questions }\end{array}$ & $91.7 \%$ & Very Good \\
\hline 2 & Language & $93.3 \%$ & Very Good \\
\hline 3 & $\begin{array}{c}\text { Audio and visual } \\
\text { display }\end{array}$ & $83.3 \%$ & Very Good \\
\hline 4 & $\begin{array}{l}\text { Implementation and } \\
\text { software engineering }\end{array}$ & $89.2 \%$ & Very Good \\
\hline 5 & Usefulness & $93 \%$ & Very Good \\
\hline \multicolumn{2}{|c|}{ Average Overall Value } & $90.2 \%$ & Very Good \\
\hline
\end{tabular}

Table 3 shows that the overall average media rating was $90.2 \%$ with very good criteria. the aspect which has the highest average feasibility percentage is the language aspect which is $93.3 \%$. In the aspect of language indicators included in the item are about the use of language that is easy to understand. That is, with the greatest percentage of students' opinion that the language used in mobile learning media is easily understood by students as users.

\subsubsection{Large Scale Media Trial by Students}

Large-scale media trial phase aims to determine the final level of mobile learning media assessment by students on a large scale or broader scope. Respondents with large-scale media trials were more numerous than small-scale media trials with 42 respondents who were students of Jakarta State University. The procedure used to get an assessment from students in the large-scale trial phase is the same as the small-scale trial phase procedure.

\section{"Mobile learning media Indonesian Language Course, is very helpful in quiz or learning, because it is interesting and easy to understand. The advice hopefully can be developed for iOS users."}

(Comments and suggestions, Student 14)

"It's good to continue to innovate again and the delivery of the video hopefully can remain interesting"

(Comments and suggestions, Student 27)
Based on the results of student comments and suggestions there are several suggestions for future media development, namely suggestions for incorporating mobile learning applications into the Appstore/ Playstore platform so that they are easy to obtain. With the learning media with mobile learning makes learning for students interesting, and not boring with the learning videos, quizzes and music.

Large-scale media assessment by students using a questionnaire consists of five aspects, namely aspects of material, video and questions, aspects of language, aspects of audio and visual appearance, aspects of software management and engineering and aspects of usefulness. Based on calculations, the results of a large-scale media trial by students in each aspect are as follows:

Table 4. Media Trial Results by Large-Scale Students

\begin{tabular}{|c|c|c|c|}
\hline No & Aspect & $\begin{array}{c}\text { Average } \\
\text { Percentage }\end{array}$ & Criteria \\
\hline 1 & $\begin{array}{c}\text { Quality of material, } \\
\text { videos and questions }\end{array}$ & $93.8 \%$ & $\begin{array}{c}\text { Very } \\
\text { Good }\end{array}$ \\
\hline 2 & Language & $95.2 \%$ & $\begin{array}{c}\text { Very } \\
\text { Good }\end{array}$ \\
\hline 3 & Audio and visual display & $91.1 \%$ & $\begin{array}{c}\text { Very } \\
\text { Good }\end{array}$ \\
\hline 4 & $\begin{array}{c}\text { Implementation and } \\
\text { software engineering }\end{array}$ & $91.7 \%$ & $\begin{array}{c}\text { Very } \\
\text { Good }\end{array}$ \\
\hline 5 & Usefulness & $95.0 \%$ & $\begin{array}{c}\text { Very } \\
\text { Good }\end{array}$ \\
\hline \multicolumn{2}{|c|}{ Average Overall Value } & $93.4 \%$ & $\begin{array}{c}\text { Very } \\
\text { Good }\end{array}$ \\
\hline
\end{tabular}

Table 4 shows that in the large-scale trial the percentage rating overall was $93.4 \%$ with the "very good" criteria.

The aspect of media assessment which has the highest percentage of assessment in large-scale media trials is the aspect of language and aspect of usefulness that is equal to $95.2 \%$ and $95 \%$ with very good criteria. Mobile learning in learning has many benefits that are good for student learning, so that mobile learning media are feasible to be a supporting medium for learning Indonesian in and outside the classroom. This is in line with the statement of [7] which states that learning by using mobile learning not only benefits students to learn at any time but also increases interest in learning and the learning process more effectively. Learning designed with mobile learning is more innovative so that it is more easily digested by students and learning is more fun [14].

\subsection{Final Product Revision}

The final product revision is the result of the evaluation of media assessment at the large-scale trial phase, so that the developed media can be used optimally and in accordance with the needs of students as mobile learning users. Mobile learning media products that have been refined at the final product revision stage are expected to be useful for students in supporting independent learning and benefits for lecturers as supporting teaching and learning 
resources in the classroom. Following is the display of Indonesian mobile learning media:

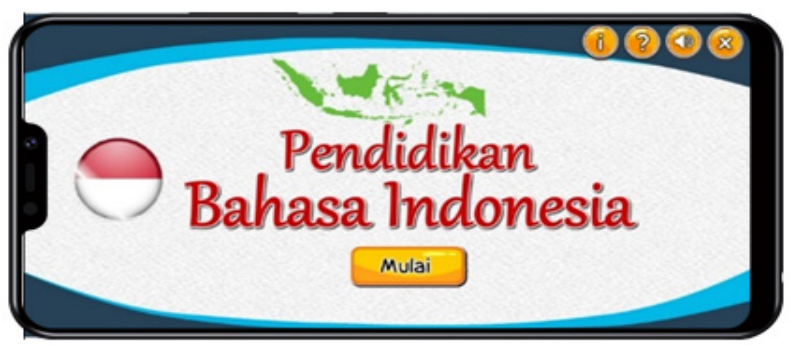

Figure 3. Initial Display of Indonesian Mobile Learning

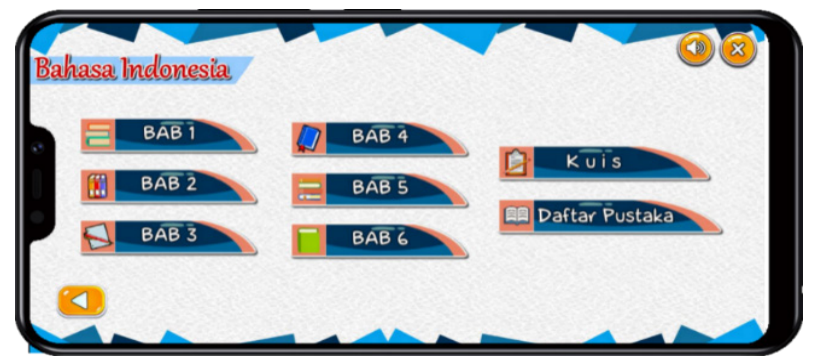

Figure 4. Initial Display of Indonesian Language Mobile Learning Materials

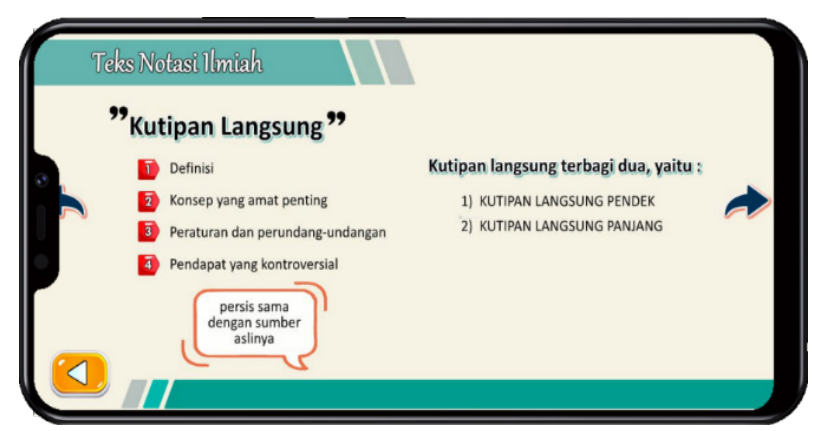

Figure 5. Display of Indonesian Language Mobile Learning Materials

\subsection{Media Effectiveness Test}

Media that have been tested on students have been tested for effectiveness to determine an increase in students' cognitive abilities after learning to use mobile learning. Media effectiveness test is done by looking at the n-gain value. Data obtained from the pre-test and post-test instruments, then compared the control class with the experimental class. The average n-gain of the control class was 0.49 , which was categorized as an increase in moderate learning outcomes and the experimental class was 0.71 , which were categorized as having a high increase in learning outcomes. Besides calculating the n-gain value, homogeneity calculation is also done to find out good data is homogeneous data.

After homogeneity testing, $t$-test was performed. $T$ test is done to test the hypothesis. The hypothesis used is:

$\mathrm{H}_{0}$ : There is no increase in the average test scores of students after using mobile learning.

$\mathrm{H}_{1}$ : There is an increase in the average student test scores after using mobile learning.

Based on probability:

$\mathrm{H}_{0}$ is accepted if significant $>0,05$

Ho is not accepted if significant $<0,05$

Based on table 5 , it is obtained $t$ count $>t$ table at alpha 0.05 is generated, so Ho is rejected. This means that the average value of post-test and pre-test results of the experimental class were significantly higher than the control class. It can be concluded that there was also a significant change in student grades after using mobile learning, this can be seen from the average post-test scores in experimental class are higher than control class. In the experimental class, the average student grade increased from 60,4 to 88,9 . Pre-test is given before students do learning, while post-test is given after students do learning using mobile learning. This shows that learning by using mobile learning can improve student learning outcomes. Mobile learning can have a positive effect on learning outcomes [3]. Most students often use smartphones in their daily lives for chatting, browsing etc. The presence of a smartphone for students can have a positive impact on education that is able to use it as a support for learning resources. This is in line with research conducted by [15] learning using technology media has a significant influence on learning. [13] shows that educators need to use mobile learning to support the learning process.

With mobile learning, it makes it easier for students to learn at any time and utilize their free time with learning activities [17] This is also because mobile learning is easier to carry and can be used anywhere [16]. Research was conducted during the covid-19 pandemic, during this period learning must be done with distance learning, it is very clear that the use of mobile learning can be used at this time, by using mobile learning students can learn without the need for lecturers, students can study at home use mobile learning that is equipped with instructions and material that has been included in the media. Mobile learning makes it easy for students to study at the time and place they want. [11] stated that the most dominant use of mobile learning is that it can combine learning in school with learning outside of school electronically.

Table 5. T-test Test Results

\begin{tabular}{|c|c|c|c|c|c|c|}
\hline & \multicolumn{2}{|c|}{ Average } & \multirow{2}{*}{ N-gain } & N & \multirow{2}{*}{ t-count } & t-table \\
\cline { 2 - 3 } & Pre-test & Post-test & & \multirow{2}{*}{2,33} & 2,02 \\
\hline Control Class & 58,6 & 77,7 & 0,49 & 22 & 28 & \\
\hline
\end{tabular}

\footnotetext{
*significant 0,05
} 


\section{Conclusions}

In this research, Indonesian mobile learning media has been produced. Mobile learning that has been developed is equipped with a usage guide and a material description module. The resulting mobile learning is in the form of compatible applications on android devices from version 3.0 to the latest version. The contents of the mobile learning media consist of material, pictures, video events and video material, practice questions, and examinations.

The results of the feasibility test and the testing of mobile learning media showed that the developed Indonesian mobile learning was appropriate to be used with very good criteria. The results of the effectiveness test through the implementation of learning in the classroom showed that the use of mobile learning media provides better learning outcomes with an increase in the post-test scores. Mobile learning can have a positive impact on education that is able to use it as a support for learning resources. Thus it is hoped that this mobile learning can be used as an effort to improve the quality of lectures at the education universities in Indonesian.

\section{Acknowledgments}

Thanks to the Directorate of Research and Community Service, Ministry of Research and Technology/BRIN for facilitating the University of Education Consortium Assignment Grants. Thanks also to the Community Research and Development Institute of UNJ, and Unima for providing support in collaborating. Also, thanks to the mobile learning media development content team, validators, and students who helped carry out this research.

\section{REFERENCES}

[1] Abdullah, M. Amin., Islamic Studies in Higher Education in Indonesia Challenges, Impact and Prospects for the World Community, Al-Jāmi'ah: Journal of Islamic Studies, 55,2, 391-426, Bumi Aksara, 2017.

[2] Alrazeeni, D., M-Learning in EMS Education - Saudi Arabia Perspective, Journal of Education and Practice, 2016.

[3] Cahyana, U., Paristiowati, M., Savitri, D. A., \& Hasyrin, S. N., Developing and Application of Mobile Game Based Learning (M-GBL) for High School Students Performance in Chemistry, EUROASIA Journal of Mathematics Science and Technology Education, 2017.
[4] Cahyana, U., Paristiowati, M., Marwa Y., Erdawati A., Rahmawati Y., Mobile Learning to Development of Students' Self-concept of Chemistry, Universal Journal of Educational Research, 2019.

[5] Cepy, R., Learning Media, Directorate General of Islamic Education, 2012.

[6] Djaali, Measurement in Education. Jakarta: Grasindo, 2008

[7] Huang, C. S. J., Yang, S. J. H., Chiang, T. H. C., \& Su, A. Y. S., Effects of Situated Mobile Learning Approach on Learning Motivation and Performance of EFL Students, 19, 263-276, 2016.

[8] Jordan, J. T., Effectiveness of Student-Generated Video as a Teaching Tool for an Instrumental Technique in the Organic Chemistry Laboratory, J Chem. Educ., pp:A-D, 2015.

[9] Kukulska-Hulme, A., \& Shield, L., An overview of mobile assisted language learning: From content delivery to supported collaboration and interaction, European Association for Computer Assisted Language Learning, 2008.

[10] Nalliveettil, G. M., \& Khaled Alenazi, T. H., The Impact of Mobile Phones on English Language Teaching: Perceptions of EFL undergraduates, Journal of Language Teaching \& Research, 7(2), 264-272, 2016.

[11] Nguyen, L., Barton, S. M., \& Nguyen, L. T., IPads in higher education - Hype and hope, British Journal of Educational Technology, 46, 1, 190-203, 2015.

[12] Ozdamli, F., \& Cavus, N., Basic elements and characteristics of mobile learning, Procedia - Social and Behavioral Sciences, 28, 937-942, 2011.

[13] Ozdamli, F., \& Uzumboylu, H, 2015, M-Learning adequacy and perceptions of students and teachers in secondary schools, 46, 1, 159-173, 2015.

[14] Ozer, O., \& Kiliç, F., The effect of mobile-assisted language learning environment on EFL students' academic achievement, cognitive load and acceptance of mobile learning tools, Eurasia Journal of Mathematics, Science and Technology Education, 14, 7, 2915-2928, 2018.

[15] Sakat, A. A., Mohd Zin, M. Z., Muhamad, R., Ahmad, A., Ahmad, N. A., \& Kasmo, M. A., Educational technology media method in teaching and learning progress, American Journal of Applied Sciences, 9, 6, 874-878, 2012.

[16] Williams, A. J., \& Pence, H. E., Smart phones, a powerful tool in the chemistry classroom, Journal of Chemical Education, 88, 6, 683-686, 2011.

[17] Wu, W. C., \& Perng, Y. H., Research on the correlations among mobile learning perception study habits, and continuous learning, Eurasia Journal of Mathematics, Science and Technology Education, 12,6, 1665-1673, 2016. 